\title{
30 GEOLOGICAL MODEL OF THE CRIMEAN TRAINING GEOLOGICAL GROUND
}

\author{
D. O. Mashin 1,2 \\ ${ }^{1}$ Institute of Geology of Komi SC UB RAS, Syktyvkar, \\ ${ }^{2}$ Syktyvkar State University named after Pitirim Sorokin, denis.mashin@gmail.com
}

The 3D geological model of the Crimean training ground is presented. The model represented a three-dimensional structural and tectonic wireframe mesh with thickness $700 \mathrm{~m}$ and area $90 \mathrm{sq}$. km and interpreted spatial relationship of MZ-KZ rocks and faults.

Keywords: 3D geological model, computer modeling, Crimean training geological ground.

\section{ТРЕХМЕРНАЯ ГЕОЛОГИЧЕСКАЯ МОДЕЛЬ КРЫМСКОГО УЧЕБНОГО ГЕОЛОГИЧЕСКОГО ПОЛМГОНА}

\author{
Д. О. Машин ${ }^{1,2}$ \\ ${ }^{1}$ Институт геологии Коми НЦ УрО РАН, Сыктывкар \\ ${ }^{2} \mathrm{CГУ} \mathrm{им.} \mathrm{Питирима} \mathrm{Сорокина}$
}

\begin{abstract}
Представлена трехмерная геологическая модель Крымского учебного полигона. Модель представляет собой трехмерный структурно-тектонический каркас мощностью 700 м и площадью 90 км², который интерпретирует пространственное взаимоотношение пород MZ-KZ-возраста и дизъюнктивной тектоники.
\end{abstract}

Ключевые слова: трехмерная геологическая модель, компьютерное моделирование, Крымский учебный геологический полигон.

\section{Introduction}

Three-dimensional geological modeling has become an integral part of study of the Earth's structure and prospecting, exploration and mining since the late 1980s. Starting with the first maps of the Earth many researchers tried to depict the volumetric subsurface structure using graphical methods: geological sections, structural maps, block diagrams. Software and hardware development of computer graphics, as well as the requirements for the development of minerals and hydrocarbons, resulted in a whole class of specialized software designed to simplify the challenges faced by scientists, geologists, designers in the study and exploration of mineral resources.

The number of foreign and Russian software packages, including possibility of constructing $3 \mathrm{D}$ geological models, is sufficiently large. They are conventionally divided by industry sector, because the manufacturers are orientated to a particular segment of consumers. The Russian literature, recently dedicated to $3 \mathrm{D}$ modeling, includes $[1,3,4]$. In the foreign literature the most complete three-dimensional geological modeling from the theoretical point of view is considered in the works [12, 13].

The Institute of geology, Komi Scientific Center, Ural Branch of Russian Academy of Sciences, since the late 1980s has paid a great attention to both theoretical [9] and practical [2, p. 41] aspects of 3D geological modeling. At the Department of geology at Syktyvkar State University they teach «Introduction to Micromine» and «Mining and geological modeling», where the students learn the basics of creating 3D geological models in Micromine software. The knowledge and skills, acquired by the students in these classes, allow them to build models of geological bodies. One of such modeling objects is a training geological ground for many national universities (Moscow State University, MGRI-RGGRU, St. Petersburg State University, Syktyvkar State University and others), located in the Bakhchisarai area of Crimea.

Despite more than 60 years of study of the geological structure of the training ground, and more than 20 years of active development of 3D geological modeling systems, three-dimensional models for the given ground has not yet been created. A detailed list of electronic publications on the geology of the area in question is prepared by the team of authors on the basis of the library at Crimean training facilities [5].

\section{Methods and approaches}

The initial and one of the most difficult stages of modeling is the collection, summary and analysis of all the information on the project. For example, the list of publications on the geology of the Crimea has more several hundred works [5], but the authors' opinions on the geological structure of the territory do not always agree.

To construct our model we selected the most developed and well illustrated geological concept by V. V. Yudin [10]. The required initial data for modeling included a geological map of the river basins Bodrak and Alma [10, p. 170], tectonic section No. 2 section of Cape Ay-Todor Belbek River [10, p. 154], and No. 3. Gurzuf - Pochtovaya $[10$, p. 164], as well as training geological maps of the area of practice, scale 1:25000.

The three-dimensional model is limited in terms by a polygon of complex shape, elongated longitudinally $11 \mathrm{~km}$ and latitudinally $14 \mathrm{~km}$ (Fig. 1). Vertically the model is limited by the sea level surface $(0 \mathrm{~m})$ and the plane at seven hundred meters above the sea level. The model is represented by a set of three-dimensional polygonal objects wireframe meshes, which, in turn, are divided into restricting closed areas - volumetric and surface wireframes.

The volumetric wireframes model bodies with thickness in scales of the model - sedimentary and volcanicsedimentary rocks, bodies of chaotic brecciated rocks mélanges (Fig 3, 4) [7, 8]. The surface wireframes model faults planes with unexpressed thickness of their outcrops (Fig. 2, 4) [6]. The 3D wireframes are composed of roof and bottom of the corresponding stratigraphic unit, surface of outcrop and restricting planes. The dynamic image most clearly represents the structure of the model $[6,7,8]$.

The relief of day surface is a digital surface model built by TIN on the topographic map of scale 1:50 000, with isohypses $10 \mathrm{~m}$. The digital model can be the basis for a vari- 


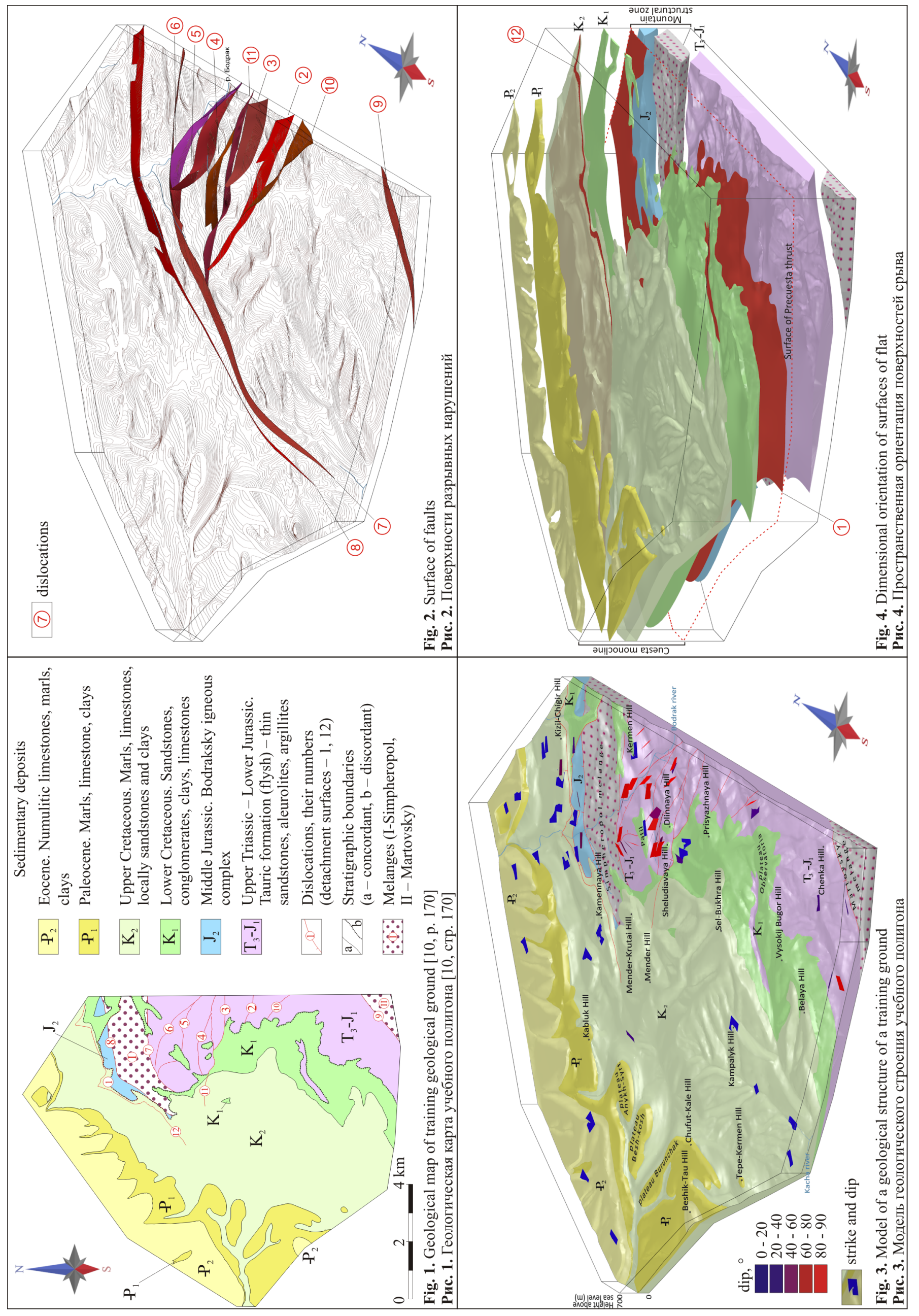


ety of independent geological, geophysical and ecological researches.

Tectonically the ground is located in Crimean Mountain fold-thrust region confined in the north and south by Mountain and South Crimean sutures. Within the Crimean Mountain fold-thrust region there are structure of a lower order - Cuesta monocline and Mountain structural zone (Figure 4). The boundary between them is a layered Precuesta thrust (No. 1 in Figs. 1 and 4) of regional scale [11]. The thrust is confined to the Lower Cretaceous members and partially overlying strata, and gently dips northward.

Cuesta monocline within the ground is represented by the Lower Cretaceous-Eocene, with the north-east strike and shallow dipping at $7-12^{\circ}$. The Mountain zone is represented by the melanges - Simferopol and Martovsky, as well as complexes of the flysch formation of Tauric series $\left(\mathrm{T}_{3}-\mathrm{J}_{1}\right)$, and volcanic-sedimentary strata of bodraksky volcanic complex $\left(\mathrm{J}_{2}\right)$.

The faults were divided into the following groups:

- group of strike faults NW strike within the flysch of Tauric series (No. 2, 3, 4, 5, 6, 10 in Figure 1 and 2);

- endogenous tectonic contacts (No. 7, 8, 9 in Figure 1,2) constraining the Simferopol and Martovsky melanges (No. I, II in Figure 1, 3);

- Cenozoic dislocation with thrusting of Tauric flysch on the Lower Cretaceous rocks (No. 11 in Figure 1 and 2);

- Sublayered thrusts at the base of the Upper Cretaceous argillaceous limestones (No. 12 in Figure 1, 4.);

- tectonic remains of upper parts of mountains Dlinnaya, Sheludivaya, Patil, which are analogues of regional Precuesta thrust fault (Figure 1 the boundary is presented by discordant stratigraphic contact).

To display the characteristics of the occurrence elements in three-dimensional space we made a program to calculate the position of the corner points of a square with given values of dip and strike (Fig. 3). The color of the square reflects the angle of dip from a cold, blue color (small angles of dip) to a warm, red color (large angles of dip). The orientation of the plane of the square corresponds to the strike. In our opinion, the occurrence elements is more visible via this method [7] in the volumetric model compared to the conventional method.

\section{Results and discussion}

On the basis of the model it is possible, at a qualitatively new level and with mathematical precision, to process and obtain new data on the balanced geological structure of the territory. This concerns geological sections, structural maps and maps of thickness, which in turn can be used for paleostructural reconstructions, geostatistical analysis and forecast of lithological characteristics of rocks that compose the studied territory, as well as for three-dimensional palinspastic and 3D geodynamic reconstructions. The disadvantage of the $3 \mathrm{D}$ geological modeling is relatively high labor costs, which are compensated by the reduction of time and high accuracy of solution of different tasks, possibility of extension and scaling of results. One of the major advantages of 3D geological model over the traditional methods of mapping: geological maps, sections, structural map - is that it combines them all in one workspace, thereby eliminating the possibility of the slightest inconsistencies.

\section{Conclusions}

We consider that modern studies of geological structure, such as geological and structural reconstructions, structural analysis, should include 3D geological modeling. The possibility of $3 \mathrm{D}$ model implies that the materials, on which it is based, are balanced and consistent.

\section{References}

1. Zakrevsky K. E. Geologicheskoe 3D modelirovanie (Geological 3D modeling). Moscow, Maska, 2009, 376 pp.

2. Institute of Geology: results and publications in 2011. Syktyvkar, Geoprint, 2012, 41 pp.

3. Kaputin Yu. E. Gornye komp'yuternye tehnologii i geostatistika (Mountain computer technology and geostatistics). St. Petersburg, Nedra, 2002, 424 pp.

4. Korotaev M. V., Pravikova N. V., Apletalin A. V. Informatsionnye tehnologii v geologii (Information technologies in geology). Moscow, KDU, 2012, 298 pp.

5. The literature on the geology of the Crimea in electronic format . comp. and ed. Rogov M. A., Ippolitov A. P., Zakharov V. A., Baraboshkin E. Yu., Kiselev D. N. URL: http://www. jurassic. ru/crimea. htm (reference date: 01.05 in 2016)

6. Mashin D. O. (2016) Surface of faults of Crimean training ground [videorecording Fig. 2]. https://youtu. be/9a-aOVT5keM

7. Mashin D. O. (2016) Model of the geological structure of the Crimean training ground [videorecording Fig. 3]. https:// youtu. be/Wgm8HN-uKAU

8. Mashin D. O. (2016) Spatial orientation of detachment surfaces. Crimean training ground [videorecording Fig. 4]. https://youtu. be/ZBOTJrmQmtw

9. Tkachev Yu. A. Strukturno-statisticheskii analiz prostranstvennogo vzaimnogo raspolozheniya geologicheskih ob'ektov (Structural and statistical analysis of spatial mutual arrangement of geologicheskih objects). Ural Geology journal, 2010, No. 5, pp. 53-62.

10. Yudin V. V. Geodinamika Kryma (Crimea Geodynamics). Simferopol, DIAYPI, 2011, 336 p.

11. Yudin V. V. Podkuestovyi nadvig Kryma (Precuesta thrust in Crimea). Field practice in the system of higher education. Proceedings, 29.07-06.08.201. Simferopol, DIAYPI, 2012, pp. 87-89.

12. Mallet Jean-Laurent. Geomodeling. Applied Geostatistics series. New York: Oxford University Press, 2002. 599 p.

13. Richard H. Groshong, Jr. 3-D Structural Geology. A Practical Guide to Quantitative Surface and Subsurface Map Interpretation. Springer-Verlag, Berlin, Heidelberg, 2006. 410 p. 